Received: 15 May 2018

Accepted: 17 June 2019

Published online: 02 July 2019
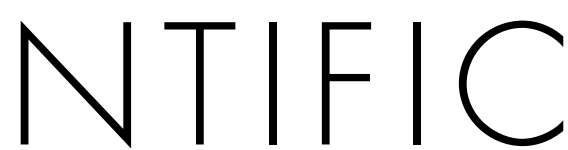

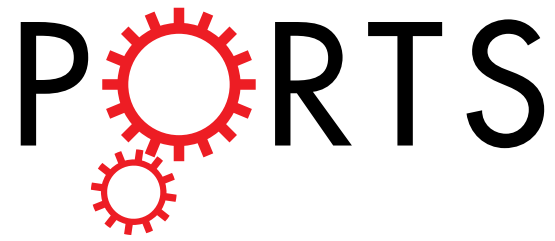

\title{
Nitric oxide acts as an antioxidant and inhibits programmed cell death induced by aluminum in the root tips of peanut (Arachis hypogaea L.)
}

Huyi He ${ }^{1,2}$, Thet Lwin $\mathrm{Oo}^{1}$, Wenjing Huang ${ }^{1}$, Long-Fei $\mathrm{He}^{1,3}$ \& Minghua Gu ${ }^{1}$

Aluminum ( $\mathrm{Al}$ ) causes programmed cell death $(\mathrm{PCD})$ in plants. Our previous studies have confirmed that nitric oxide (NO) inhibits Al-induced PCD in the root tips of peanut. However, the mechanism by which NO inhibits Al-induced PCD is unclear. Here the effects of NO on mitochondrial reactive oxygen species (ROS), malondialdehyde (MDA), activities of superoxide dismutase (SOD) and ascorbate peroxidase (APX), expression of alternative oxidase (AhAOX) and cytochrome oxidase $(A h C O X)$ were investigated in peanut (Arachis hypogaea $\mathrm{L}$.) root tips treated with Al. The results showed that Al stress induced rapid accumulation of $\mathrm{H}_{2} \mathrm{O}_{2}$ and MDA and increased the ratio of SOD/APX. The up-regulation of $A$ AOOX and AhCOX expressions was not enough to inhibit PCD occurrence. Sodium nitroprusside (SNP, a NO donor) decreased the ratio of SOD/APX and eliminated excess $\mathrm{H}_{2} \mathrm{O}_{2}$ and MDA, thereby inhibiting Al-induced $P C D$ in the root tips of peanut. The expression of $A h A O X$ and $A h C O X$ was significantly enhanced in Al-induced PCD treated with SNP. But CPTIO (a NO specific scavenger) supply had the opposite effect. Taken together, these results suggested that lipid peroxidation induced by higher levels of $\mathrm{H}_{2} \mathrm{O}_{2}$ was an important cause of Al-induced PCD. NO-mediated inhibition of Al-induced PCD was related to a significant elimination of $\mathrm{H}_{2} \mathrm{O}_{2}$ accumulation by decreasing the ratio of SOD/APX and up-regulating the expression of $A h A O X$ and $A h C O X$.

As a major factor, aluminum (Al) toxicity limits crop productivity in acid soil. Al inhibits root elongation growth and disrupts the uptake of nutrient and water in plants. Al enhanced the production of reactive oxygen species (ROS), leading to mitochondrial respiration inhibition and ATP depletion in plant cells ${ }^{1}$. Al exclusion and tolerance mechanisms are associated with mitochondrial metabolism, especially organic acid transport and mitochondrial activity ${ }^{2}$. Programmed cell death (PCD) is a process of cellular suicide controlled by genes. Al toxicity may be the result of Al-induced PCD in the root tips of barley ${ }^{3}$. The negative regulation of PCD alleviated Al toxicity in yeast ${ }^{4}$. Our previous researches showed that $\mathrm{Al}$ induced mitochondria-dependent PCD in Al-sensitive peanut cultivar rapidly ${ }^{5}$.

Nitric oxide (NO) has been considered as a signal regulator involved in plant growth and stress tolerance. $\mathrm{Al}$ stress changes the homeostasis of endogenous NO in plants ${ }^{6}$. Exogenous NO donor sodium nitroprusside (SNP) treatment can alleviate $\mathrm{Al}$ toxicity by ameliorating effectively Al-induced mitochondrial respiratory dysfunction in wheat root tips ${ }^{7}$. The former studies of our group had showed that NO suppresses PCD induced by Al in peanut root tips ${ }^{8}$. NO may be an antioxidant to postpone PCD in barley aleurone layers ${ }^{9}$. However, the mechanism by which NO inhibits Al-induced PCD is unclear.

As an important power station, mitochondrion is mainly responsible for electron transport, oxidative phosphorylation, and energy metabolism in animal and plant cells. Higher concentrations of Al treatment opened the mitochondrial membrane permeability transition pore (MPTP) and released cytochrome c (Cyt c) into the cytoplasm, thereby induced PCD in peanut root tips ${ }^{10}$. In Arabidopsis thaliana, Al toxicity induced mitochondria-dependent $\mathrm{PCD}^{11}$. Oxidative stress increased ROS generation, the opening of MPTP, and activation of proteases, leading to the occurrence of PCD in Arabidopsis cells ${ }^{12}$. In the early stages of PCD in

${ }^{1}$ College of Agronomy, Guangxi University, Nanning, 530004, P.R. China. ${ }^{2}$ Cash Crops Research Institute, Guangxi Academy of Agricultural Sciences, Nanning, 530007, P.R. China. ${ }^{3}$ Guangxi Key Laboratory for Agro-Environment and Agro-Product Safety, Nanning, 530004, P.R. China. Correspondence and requests for materials should be addressed to L.-F.H. (email: Ifhe@gxu.edu.cn) 
heat-shocked tobacco BY-2 cells, cytosolic ascorbate peroxidase (cAPX) was damaged and ROS were generated with the injury of mitochondrial metabolism ${ }^{13}$. ROS can trigger Cyt $c$ release and the activation of caspase-like proteases is required to cause cell death ${ }^{14}$. As the regulatory center of PCD, the structure and function of mitochondria also played a vital role during Al-induced PCD in peanut ${ }^{15}$. In the root tip cells of peanut, Al-induced ROS burst activated mitochondria-dependent $\mathrm{PCD}^{16}$. The over-reduction of mitochondrial electron transport chain is the primary sources of ROS production in plant root tip cells ${ }^{17}$. Alternative oxidase (AOX) is the terminal oxidase of the cyanide-resistant respiration pathway in the mitochondrial respiratory chain of plants. Cytochrome c oxidase (COX) is a kind of cytochrome oxidase located in the terminal of the mitochondrial respiratory chain. Under stress condition, AOX and COX can change the level of respiratory metabolism, scavenge ROS, and regulate cell function. The suppression of NO on Al-induced PCD was associated with the improvement of mitochondrial physiological properties in peanut root tips ${ }^{18}$. Whether mitochondrial ROS are involved in the inhibition of Al-induced PCD by NO has not been reported.

In the present study, to explore the mitochondrial pathway of NO regulating Al-induced PCD, the effects of treatment with NO donor and NO specific scavenger on mitochondrial ROS, malondialdehyde (MDA), activities of superoxide dismutase (SOD) and ascorbate peroxidase (APX), expression of $A h A O X$ and $A h C O X$ under $\mathrm{Al}$-induced PCD in the root tips of peanut were investigated. These results indicated that excess $\mathrm{H}_{2} \mathrm{O}_{2}$-induced lipid peroxidation was an important cause of Al-induced PCD. NO-mediated inhibition of PCD induced by Al was related to a significant decrease in the ratio of SOD/APX and the up-regulation of $A h A O X$ and $A h C O X$ expressions.

\section{Results}

Evaluation of mitochondrial function. To evaluate the mitochondrial function, the membrane potential and Cyt $\mathrm{c}$ value were detected. The mitochondrial membrane potential can be expressed as the fluorescence intensity of the fluorescent probe $\mathrm{Rh}-123$. The results showed that the fluorescence intensity of the control and $\mathrm{Al}$ treatment were 0.89 and 0.56 , respectively. After Al treatment, Cyt c value decreased from $21.4 \mathrm{nmol}^{\prime} \mu \mathrm{g}^{-1}$ Pro to $9.2 \mathrm{nmol} \cdot \mu \mathrm{g}^{-1}$ Pro. This indicated that the mitochondrial function was pure, integral, and viable.

Effects of Al on mitochondrial $\mathrm{O}_{2} \cdot{ }^{-}, \mathrm{H}_{2} \mathrm{O}_{2}$, and lipid peroxidant. When plants are exposed to adversity stress, a lot of ROS are produced and excess ROS do harm to plants. To study the effects of Al on mitochondrial ROS and lipid peroxidant, peanut seedlings were exposed to $100 \mu \mathrm{mol} \cdot \mathrm{L}^{-1} \mathrm{AlCl}_{3}$ solution at different times. As $\mathrm{Al}$ treatment time extended, $\mathrm{O}_{2}{ }^{-}$production rate increased sharply to the peak at $8 \mathrm{~h}$ and then decreased slowly (Fig. 1A). Compared to the control, the mitochondrial $\mathrm{O}_{2}{ }^{--}$production rate reached a peak in the root tips of peanut at $8 \mathrm{~h}$ of $\mathrm{Al}$ treatment. As shown in Fig. 1B, the mitochondrial $\mathrm{H}_{2} \mathrm{O}_{2}$ content of peanut root tips was increased after $\mathrm{Al}$ treatment. Al treatment for $1 \mathrm{~h}$ increased significantly $\mathrm{H}_{2} \mathrm{O}_{2}$ content and then kept up at a higher level compared with the control. MDA content is always used as an indicator to estimate the level of lipid peroxidation. The results showed that the MDA content was increased sharply as $\mathrm{Al}$ treatment time increased (Fig. 1C). Compared with the control, MDA content of mitochondria was increased by 2.2 fold at the time of $4 \mathrm{~h}$ $\mathrm{Al}$ treatment in the root tips of peanut. At $12 \mathrm{~h}$ and $24 \mathrm{~h}, \mathrm{MDA}$ content increased by 3.6 fold and 6.3 fold, respectively. MDA content was increased significantly in a time-dependent manner.

Effects of Al on mitochondrial antioxidase activities. To study the effects of $\mathrm{Al}$ on mitochondrial antioxidase activities, the activities of SOD and APX were measured. The activity of SOD was gradually decreased as $\mathrm{Al}$ treatment time prolonged (Fig. 2A). Compared with the control, SOD activity of peanut root tips was decreased by $32.1 \%$ at $4 \mathrm{~h} \mathrm{Al}$ treatment. At $12 \mathrm{~h}$ and $24 \mathrm{~h}$, SOD activity had dropped by $60.7 \%$ and $71.4 \%$, respectively. The activity of APX was sharply decreased as Al treatment time increased (Fig. 2B). Compared to the control, the activity of APX in the root tips of peanut was reduced by $50 \%$ at $4 \mathrm{~h}$ of Al treatment. At $12 \mathrm{~h}$ and $24 \mathrm{~h}$, APX activity had dropped by $87.5 \%$ and $95.3 \%$, respectively. As Al treatment time increased, the ratio of SOD/ APX was rapidly increased (Fig. 2C).

Relationship between root cell death and $\mathrm{H}_{2} \mathrm{O}_{2}$, MDA, SOD/APX in peanut root tips. As shown in Fig. 3A,C, $\mathrm{H}_{2} \mathrm{O}_{2}$ content in mitochondria of the peanut root tips was significantly positively correlated with not only cell death $\left(\mathrm{R}^{2}=0.993\right)$ but also SOD/APX $\left(\mathrm{R}^{2}=0.885\right)$. However, the correlation between cell death and superoxide was very poor $\left(\mathrm{R}^{2}=0.044\right)$. There was a significantly positive relationship between lipid peroxidation and cell death in peanut root tips $\left(\mathrm{R}^{2}=0.935\right)$ (Fig. 3B). Fig. 3D showed that SOD/APX was significantly positively correlated with cell death in the root tips of peanut $\left(\mathrm{R}^{2}=0.857\right)$.

Effects of $\mathrm{NO}$ on $\mathrm{O}_{2} \cdot{ }^{-}, \mathrm{H}_{2} \mathrm{O}_{2}$, and MDA in the root tips of peanut. To study the effects of NO on mitochondrial ROS and lipid peroxidation, peanut seedlings were exposed to different chemical treatments. As shown in Fig. 4A, NO decreased mitochondrial $\mathrm{O}_{2} \cdot-$ production rates in the root tips of peanut. Compared with Al treatment alone, SNP effectively inhibited the production of mitochondrial $\mathrm{O}_{2}{ }^{--}$, while cPTIO (a NO specific scavenger) significantly increased the production rate of $\mathrm{O}_{2}{ }^{-}{ }^{-}$. As shown in Fig. $4 \mathrm{~B}, \mathrm{NO}$ inhibited $\mathrm{H}_{2} \mathrm{O}_{2}$ production by mitochondria in the root tips of peanut. Compared with $\mathrm{Al}$ treatment, SNP significantly inhibited the production of mitochondrial $\mathrm{H}_{2} \mathrm{O}_{2}$, while cPTIO intensified $\mathrm{H}_{2} \mathrm{O}_{2}$ content. As shown in Fig. 4C, NO decreased mitochondrial MDA content in peanut root tips. Compared to Al treatment alone, SNP significantly reduced mitochondrial MDA content in the root tips of peanut, while cPTIO significantly increased MDA content.

Effects of NO on SOD, APX, and SOD/APX in the root tips of peanut. To study the effects of NO on mitochondrial antioxidase activities, the activities of SOD and APX were measured under different chemical treatments. As shown in Fig. 5A, Al treatment inhibited the activity of mitochondrial SOD in the root tips of peanut. Compared to Al treatment alone, SNP significantly increased the activity of SOD, while cPTIO significantly 
$\mathbf{A}$
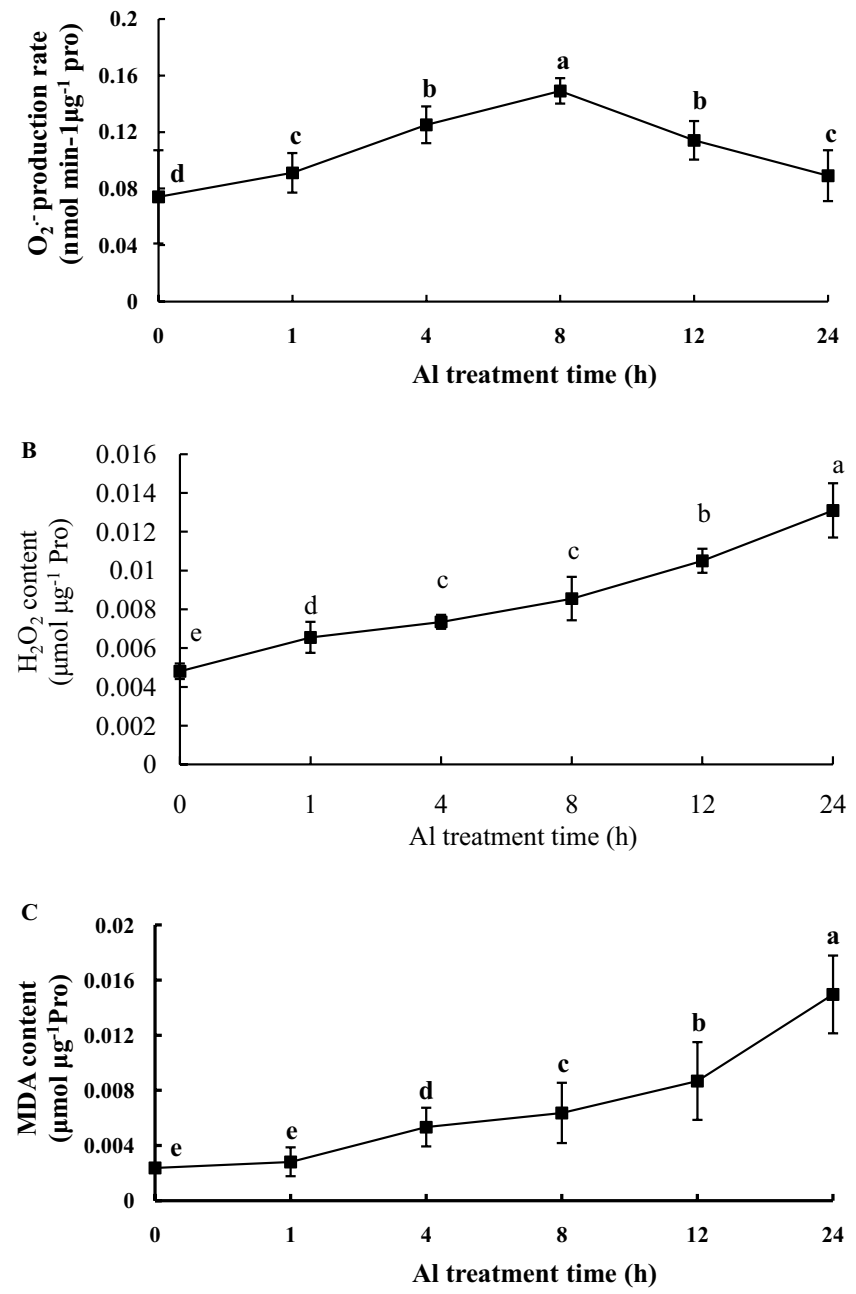

Figure 1. Changes of mitochondrial $\mathrm{O}_{2} \cdot-$ production rate (A), $\mathrm{H}_{2} \mathrm{O}_{2}$ content (B) and MDA content (C) in peanut roots under $100 \mu \mathrm{mol} \cdot \mathrm{L}^{-1} \mathrm{AlCl}_{3}$ treatment for $0 \mathrm{~h}$ (control), $1 \mathrm{~h}, 4 \mathrm{~h}, 8 \mathrm{~h}, 12 \mathrm{~h}$, and $24 \mathrm{~h}$. Each data in figure represents the mean $\pm \mathrm{SD}$ of three experiments. Different lower case letters indicate significance at $P<0.05$ compared to the control.

reduced the activity of SOD. As shown in Fig. 5B, Al treatment inhibited the activity of mitochondrial APX in the root tips of peanut. Compared to Al treatment alone, SNP significantly increased the activity of APX, while cPTIO significantly reduced the activity of APX. The addition of SNP decreased the ratio of SOD/APX, which was increased by Al treatment, while cPTIO supplement increased the ratio of SOD/APX (Fig. 5C).

Effects of NO on AhAOX and AhCOX expression during Al-induced PCD. The expression of $A h A O X$ was rapidly increased and then slowly decreased under $\mathrm{Al}$ stress (Fig. 6A). After $1 \mathrm{~h}$ of $\mathrm{Al}$ treatment, the expression of $A h A O X$ was increased, indicating that $\mathrm{Al}$ boosted the expression of this gene. At $4 \mathrm{~h} \mathrm{Al}$ treatment, the expression of this gene was the highest, which was 10.3 times than that of the control. The expression of $A h A O X$ was then reduced. The expression of this gene at $12 \mathrm{~h} \mathrm{Al}$ treatment was 2.22 times of the control. As shown in Fig. 6B, compared to Al treatment alone, the addition of SNP increased significantly the expression of $A h A O X$, an increase of $919.65 \%$; cPTIO supplement decreased the expression of $A h A O X$, but there was no significant difference compared with Al treatment alone.

The expression of $A h C O X$ was rapidly increased and then slowly decreased under Al treatment (Fig. 6C). After $1 \mathrm{~h}$ of Al treatment, $A h C O X$ expression was increased, indicating that Al motivated the expression of this gene. At $4 \mathrm{~h} \mathrm{Al}$ treatment, the expression of this gene was the highest, which was 17.92 times than that of the control. Then the expression of $A h C O X$ was gradually decreased. The expression of this gene at $12 \mathrm{~h}$ was 1.30 times than that of the control. As shown in Fig. 6D, compared with Al treatment alone, the addition of SNP significantly increased the expression of $A h C O X$, an increase of $237.92 \%$, while the expression of $A h C O X$ for cPTIO supplement was significantly higher than that of Al treatment.

Hierarchical cluster analysis of ROS in Al-induced PCD in the root tips of peanut. Based on the data of mitochondrial $\mathrm{O}_{2}{ }^{-}, \mathrm{H}_{2} \mathrm{O}_{2}$, MDA (Fig. 1), SOD, APX, SOD/APX (Fig. 2), AhAOX (Fig. 6A), AhCOX (Fig. 6C), and cell death in the root tips of peanut with different $\mathrm{Al}$ treatment time, hierarchical cluster was conducted to analyze the interaction between $\mathrm{NO}$ and $\mathrm{ROS}$ on peanut response to $\mathrm{Al}$ stress. The results indicated that $\mathrm{Al}$ stress inhibited 
A

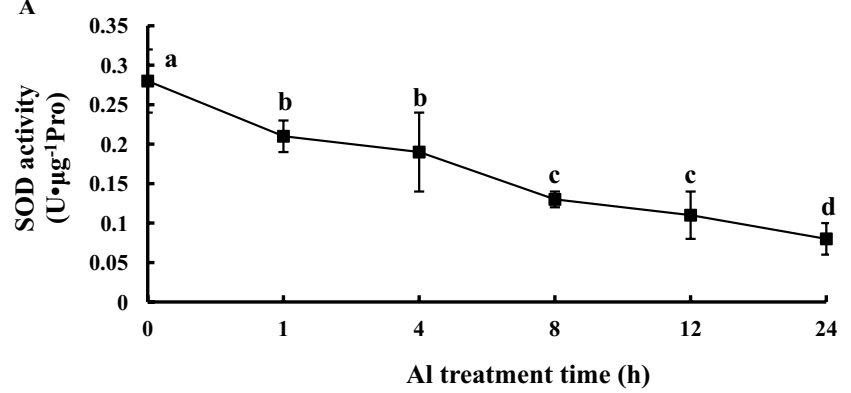

B

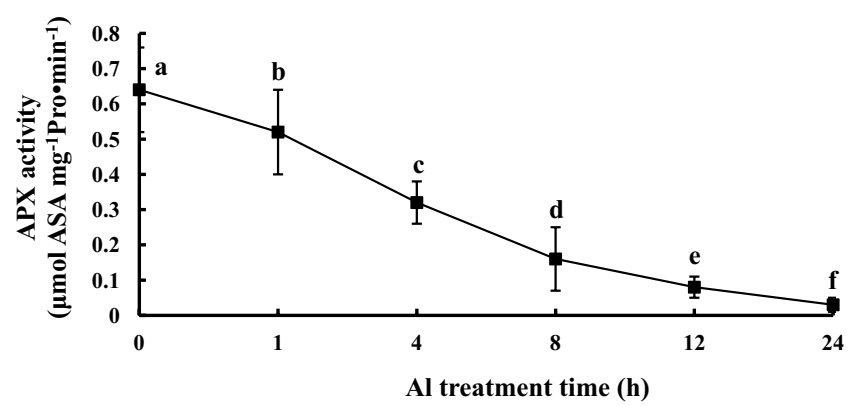

C

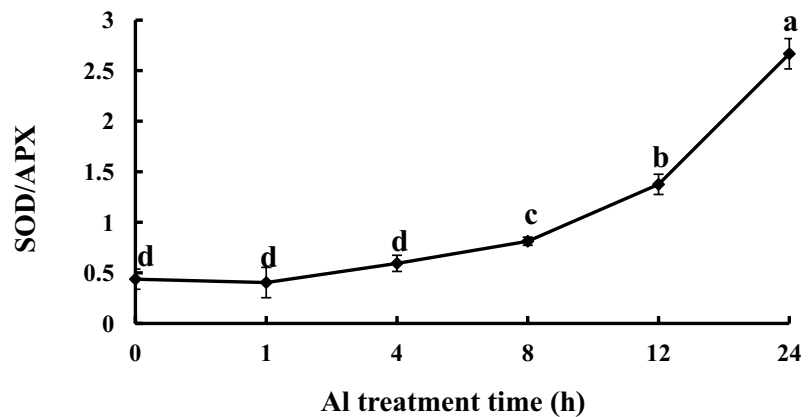

Figure 2. Changes of mitochondrial SOD activity (A), APX activity (B), and SOD/APX (C) from peanut roots under $100 \mu \mathrm{mol} \cdot \mathrm{L}^{-1} \mathrm{AlCl}_{3}$ treatment for $0 \mathrm{~h}$ (control), $1 \mathrm{~h}, 4 \mathrm{~h}, 8 \mathrm{~h}, 12 \mathrm{~h}$, and $24 \mathrm{~h}$. Each data in figure represents the mean \pm SD of three experiments. Different lower case letters indicate significance at $P<0.05$ compared to the control.

the activities of SOD and APX (Fig. 7a-A), increased the ratio of SOD and APX, up-regulated the expression of AhAOX and $A h C O X$ (Fig. 7a-B), promoted the accumulation of $\mathrm{H}_{2} \mathrm{O}_{2}, \mathrm{O}_{2}{ }^{-}$(Fig. 7a-C), and MDA, resulting in Al-induced PCD in peanut root tips (Fig. 7a-D). Under Al stress, the physiological parameters are clustered well to four groups (A-D). There is a causal relationship between group A and D. Group B and C are paralleled.

Hierarchical cluster analysis of ROS in NO inhibiting Al-induced PCD in the root tips of peanut. Based on the data of mitochondrial $\mathrm{O}_{2} \cdot{ }^{-}, \mathrm{H}_{2} \mathrm{O}_{2}$, MDA (Fig. 4), SOD, APX, SOD/APX (Fig. 5), AhAOX (Fig. 6B), $A h C O X$ (Fig. 6D), and cell death in the root tips of peanut with different treatments, hierarchical cluster was used to analyze the interaction between $\mathrm{NO}$ and ROS on peanut response to $\mathrm{Al}$ stress. The results indicated that NO donor SNP promoted the activities of SOD and APX (Fig. 7b-A), decreased the ratio of SOD and APX, up-regulated the expression of $A h A O X$ and $A h C O X$ (Fig. 7b-B), reduced the accumulation of $\mathrm{H}_{2} \mathrm{O}_{2}$ and $\mathrm{O}_{2}$. (Fig. 7b-C), leading to inhibition of Al-induced PCD in the root tips of peanut. cPTIO supply had the opposite effects. During NO inhibiting Al-induced PCD, the physiological parameters are clustered well to three groups $(\mathrm{A}-\mathrm{C})$. There is causal relationship between group $\mathrm{A}$ and $\mathrm{C}$. Group $\mathrm{B}$ and $\mathrm{C}$ are paralleled. Group $\mathrm{C}$ is also divided into two subgroups, which have a more direct causal relationship.

\section{Discussion}

Excessive $\mathrm{H}_{2} \mathrm{O}_{2}$-induced lipid peroxidation is an important cause of $\mathrm{Al}$-induced PCD. $\mathrm{H}_{2} \mathrm{O}_{2}$ is an unstable and strong oxidant. When $\mathrm{Fe}^{2+}$ is present, the Fenton reaction $\left(\mathrm{H}_{2} \mathrm{O}_{2}+\mathrm{Fe}^{2+} \rightarrow \mathrm{OH}^{-}+\mathrm{OH}^{\bullet}+\mathrm{Fe}^{3+}\right)$ occurs. As one of the most active ROS, the formative hydroxyl radical $\left(\mathrm{OH}^{\bullet}\right)$ is highly harmful to all biomolecules in plants including DNA, RNA, lipids, and proteins. So the excess $\mathrm{H}_{2} \mathrm{O}_{2}$ must be eliminated promptly. ROS closely related 

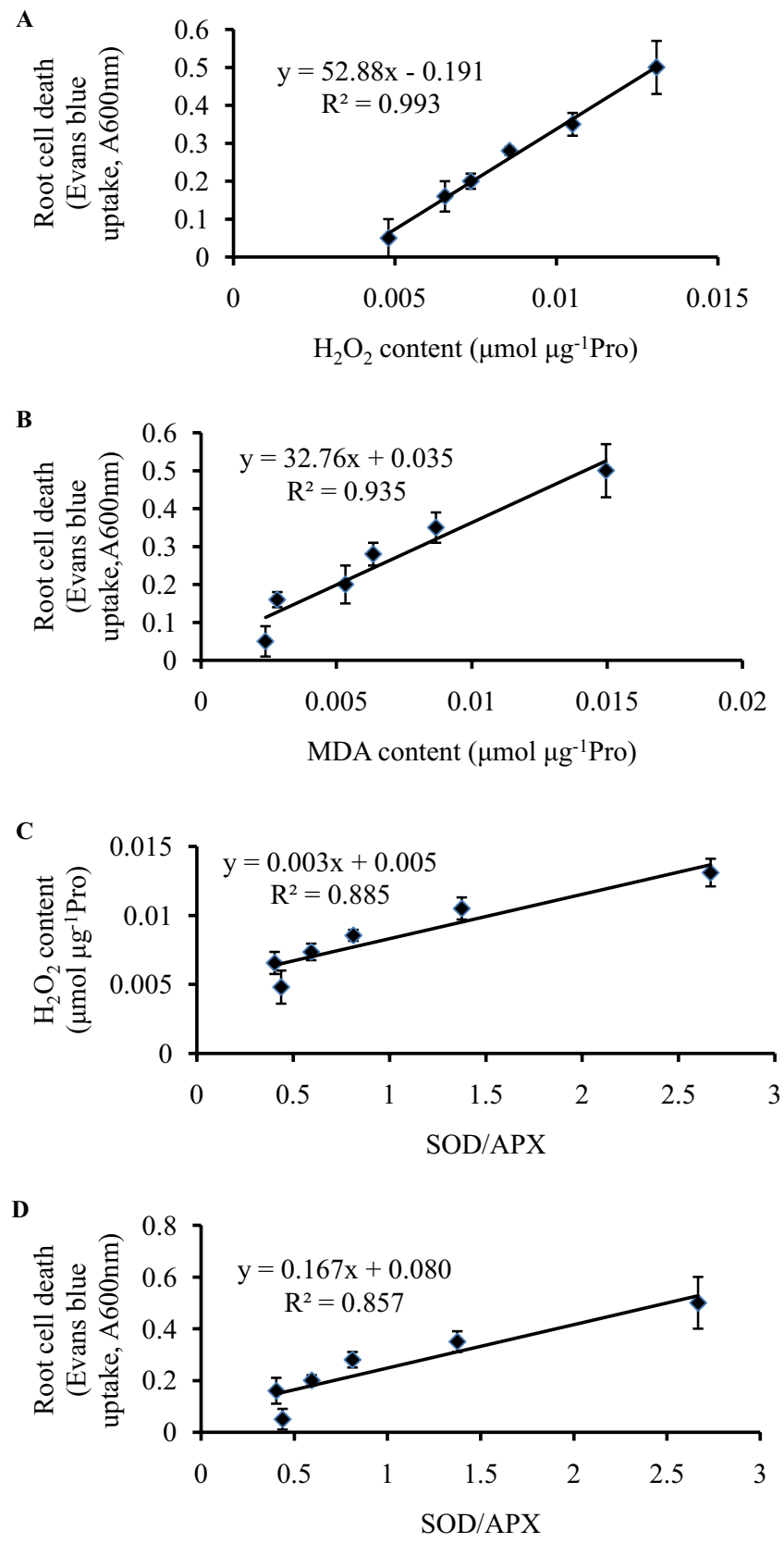

Figure 3. Relationship between root cell death and $\mathrm{H}_{2} \mathrm{O}_{2}$ content (A), MDA content (B), respectively. Relationship between SOD/APX and $\mathrm{H}_{2} \mathrm{O}_{2}$ content (C), cell death (D), respectively in peanut root tips.

with Al-induced PCD in the root tips of peanut is $\mathrm{H}_{2} \mathrm{O}_{2}$ rather than $\mathrm{O}_{2}{ }^{-}$(Fig. 3A). Cadmium (Cd) induced the accumulation of $\mathrm{H}_{2} \mathrm{O}_{2}$ in the roots of Pinus sylvestris L., induced xylem formation and accelerated senescence ${ }^{19}$. Low concentrations of Al stimulated PLC and PLD signaling pathways to lead to ROS production, followed by the caspase-like protease to execute cell death ${ }^{20}$. Moreover, the results of correlation analysis indicated that lipid peroxidation induced by higher levels of $\mathrm{H}_{2} \mathrm{O}_{2}$ might be an important cause of Al-induced PCD (Fig. 3A,B). NO can combine with $\mathrm{O}_{2}{ }^{-}$to form peroxynitrite $\left(\mathrm{ONOO}^{-}\right)$, which can induce cell death. Because $\mathrm{O}_{2}{ }^{-}$was not major ROS during Al-induced PCD, in fact, $\mathrm{ONOO}^{-}$was rarely generated.

Nitric oxide mediates inhibition of Al-induced PCD by decreasing the ratio of SOD/APX to scavenge excess $\mathrm{H}_{2} \mathrm{O}_{2}$. The decrease of SOD/APX ratio contributed to the elimination of $\mathrm{H}_{2} \mathrm{O}_{2}$ (Fig. 3C), so the increase of SOD/APX ratio may be associated with Al-induced PCD in peanut roots (Fig. 3D). NO donor SNP enhances the antioxidant capacity of wheat seedlings under $\mathrm{Al}$ stress ${ }^{21}$. NR-dependent NO production alleviated $\mathrm{Al}$-induced oxidative stress in the roots of red bean ${ }^{22}$. NO suppressed Cassia tora root sensitivity to $\mathrm{Al}$ by inactivating the cell wall peroxidase activity and reducing $\mathrm{H}_{2} \mathrm{O}_{2}$ production ${ }^{23}$. As an antioxidant, $\mathrm{NO}$ increased the activities of SOD and CAT, delay PCD in barley aleurone layers ${ }^{9}$. In the induction of plant cell death, there 

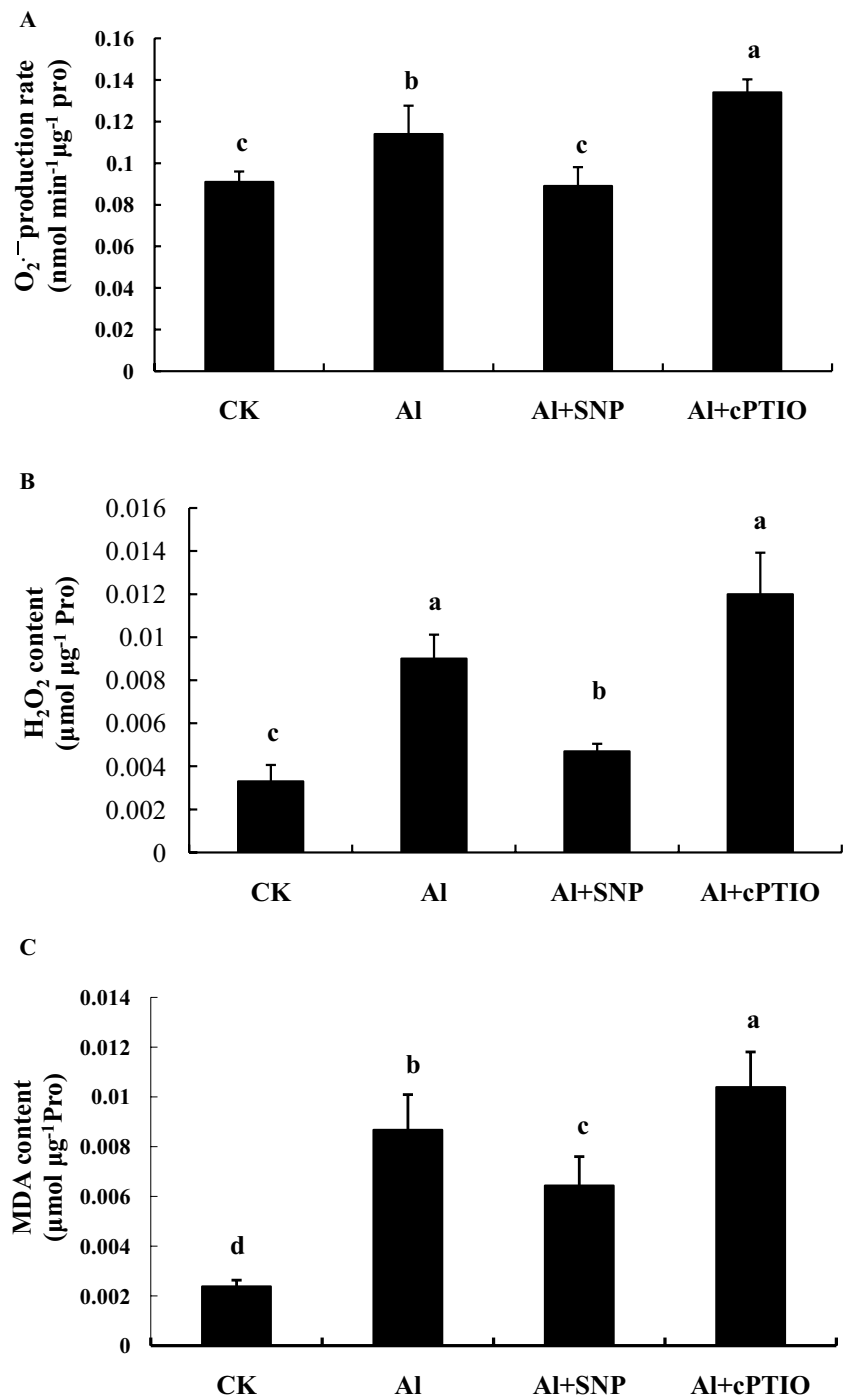

Figure 4. Changes of mitochondrial $\mathrm{O}_{2} \cdot{ }^{-}$production rate (A), $\mathrm{H}_{2} \mathrm{O}_{2}$ content $(\mathbf{B})$, and MDA content (C) from peanut roots treated with $0.1 \mathrm{mmol} \cdot \mathrm{L}^{-1} \mathrm{CaCl}_{2}\left(\mathrm{pH}\right.$ 4.2) $(\mathrm{CK}), 100 \mu \mathrm{mol} \cdot \mathrm{L}^{-1} \mathrm{AlCl}_{3}(\mathrm{Al}), 100 \mu \mathrm{mol} \cdot \mathrm{L}^{-1}$ $\mathrm{AlCl}_{3}+200 \mu \mathrm{mol} \cdot \mathrm{L}^{-1} \mathrm{SNP}(\mathrm{Al}+\mathrm{SNP})$, and $100 \mu \mathrm{mol} \cdot \mathrm{L}^{-1} \mathrm{AlCl}_{3}+50 \mu \mathrm{mol} \cdot \mathrm{L}^{-1} \mathrm{cPTIO}(\mathrm{Al}+\mathrm{cPTIO})$ for $12 \mathrm{~h}$. Each data in figure represents the mean \pm SD of three experiments. Different lower case letters indicate significance at $P<0.05$ compared to the control.

is crosstalk and synergistic action between $\mathrm{NO}$ and $\mathrm{H}_{2} \mathrm{O}_{2}{ }^{24}$. NO treatment reversed Al-induced reactive oxygen species toxicities by promoting the expression of antioxidant enzymes ${ }^{25}$. The decrease of $\mathrm{NO}$ level promoted the accumulation of ROS and induced the expression of pathogen-related proteins (PRs) to protect cells from Cd toxicity $^{26}$. NO and ROS can induce cell death alone or synergistically ${ }^{27}$. In the present study, $\mathrm{Al}$ stress decreased SOD and APX activity and raised membrane lipid peroxidation in peanut apex, while NO activated antioxidant enzymes (SOD, APX) system to protect the peanut root tip from ROS damage. The result is consistent with the findings of Wang and Yang ${ }^{28}$. Because the decreasing range of APX activity was larger than that of SOD activity, excessive $\mathrm{H}_{2} \mathrm{O}_{2}$ could not be removed in time. With the prolonging of $\mathrm{Al}$ treatment time, $\mathrm{Al}$ stress increased $\mathrm{H}_{2} \mathrm{O}_{2}$ production and MDA accumulation, which was related to the rise of SOD/APX ratio. The linear relationship between SOD/APX and $\mathrm{H}_{2} \mathrm{O}_{2}$ content also clearly indicated that the content of $\mathrm{H}_{2} \mathrm{O}_{2}$ increased with the rise of SOD/APX ratio (Fig. 3C). Acute stress generated ROS and reactive nitrogen species (RNS) and lead to APX degradation. The regulation of APX mediated by NO may be a redox sensor of oxidative stress ${ }^{29} \cdot \mathrm{H}_{2} \mathrm{O}_{2}$ alleviated salt-induced oxidative stress by modulating APX and SOD activities in cotton ${ }^{30}$. Similar to the result of Fan et al. ${ }^{31}$, NO up-regulated the activities of SOD and APX. But the rising range of APX activity was larger than that of SOD activity, resulting in the decrease of SOD/APX ratio. By decreasing the ratio of SOD/APX, SNP eliminated excess $\mathrm{H}_{2} \mathrm{O}_{2}$ and decreased MDA, thereby inhibiting Al-induced PCD in the root tips of peanut. But cPTIO supply had the opposite effect.

Inhibition of Al-induced PCD by NO is related to the enhancement of AhAOX and AhCOX expressions. AOX can be adapted to the environmental changes by regulating its own structure, which plays 
A

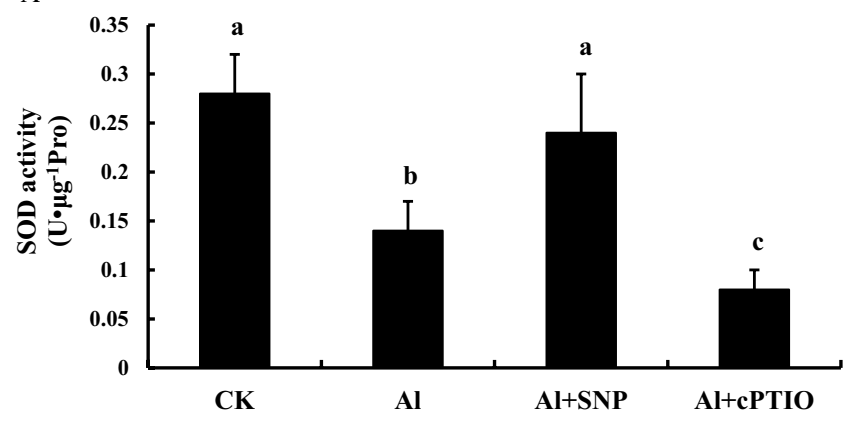

B

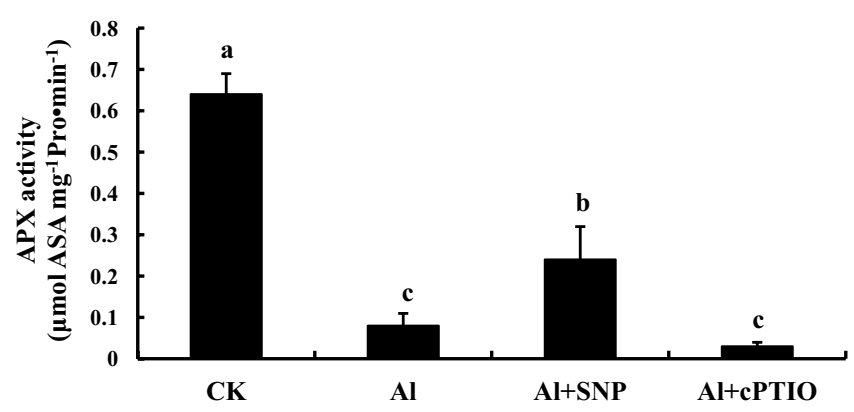

C

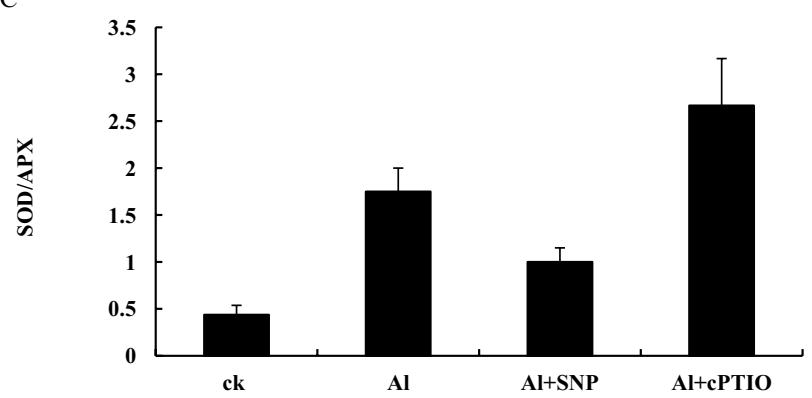

Figure 5. Changes of mitochondrial SOD activity (A), APX activity (B), and SOD/APX (C) from peanut roots treated with $0.1 \mathrm{mmol} \cdot \mathrm{L}^{-1} \mathrm{CaCl}_{2}(\mathrm{pH} 4.2)(\mathrm{CK}), 100 \mu \mathrm{mol} \cdot \mathrm{L}^{-1} \mathrm{AlCl}_{3}(\mathrm{Al}), 100 \mu \mathrm{mol} \cdot \mathrm{L}^{-1} \mathrm{AlCl}_{3}+200 \mu \mathrm{mol} \cdot \mathrm{L}^{-1}$ $\mathrm{SNP}(\mathrm{Al}+\mathrm{SNP})$, and $100 \mu \mathrm{mol} \cdot \mathrm{L}^{-1} \mathrm{AlCl}_{3}+50 \mu \mathrm{mol} \cdot \mathrm{L}^{-1} \mathrm{cPTIO}(\mathrm{Al}+\mathrm{cPTIO})$ for $12 \mathrm{~h}$. Each data in figure represents the mean $\pm \mathrm{SD}$ of three experiments. Different lower case letters indicate significance at $P<0.05$ compared to the control.

an important part in plant physiology ${ }^{32}$. AOX can effectively reduce the production of mitochondrial ROS in plant cells and decrease cell injury ${ }^{33}$. The lack of mitochondrial AOX increased susceptibility to PCD in transgenic plants, but induction of mitochondrial AOX prevented PCD by down-regulating the cytochrome pathway ${ }^{34,35}$. Salicylic acid and $\mathrm{H}_{2} \mathrm{O}_{2}$ treatment up-regulated the expression of AOX in wild type tobacco, reduced ROS accumulation in mitochondria and delayed PCD occurrence ${ }^{36}$. AOX acts as a buffer that determines the threshold of PCD induction ${ }^{37,38}$. The expression of AOX was significantly up-regulated in tobacco suspension cells treated with $500 \mu \mathrm{mol} \cdot \mathrm{L}^{-1} \mathrm{AlCl}_{3}$. Overexpression of AOX could enhance the tolerance of tobacco suspension cells to $\mathrm{Al}$ stress $^{11}$. The PCD degree of tobacco with AOX knockout was more serious ${ }^{27}$.

As the center enzyme of complex IV in the electron transport chain, COX is related to the mitochondrial respiratory metabolism and ATP synthesis ${ }^{39}$. In the present study, the results showed that $\mathrm{Al}$ stress raised membrane lipid peroxidation and up-regulated the expression of $A h A O X$ and $A h C O X$, which was not enough to inhibit PCD occurrence. The expression of $A h A O X$ and $A h C O X$ presented periodic fluctuation within 24 hours, speculating that they might be related to the biological clock. However, NO can enhance significantly the expression of $A h A O X$ and $A h C O X$, protect the peanut root tip from ROS damage. As for how NO regulates their expression via a biological clock, it needs further study.

\section{Conclusions}

Our results indicate that Al-induced PCD in the root tips of peanut is related to excessive ROS-induced mitochondrial physiological alterations by (Fig. 8). Al stress induces a large amount of mitochondrial ROS production in the root tips of peanut, causes mitochondrial membrane lipid peroxidation and mitochondria dysfunction, ultimately resulting in PCD production. But NO can enhance the expression of $A h A O X$ and $A h C O X$, improve 

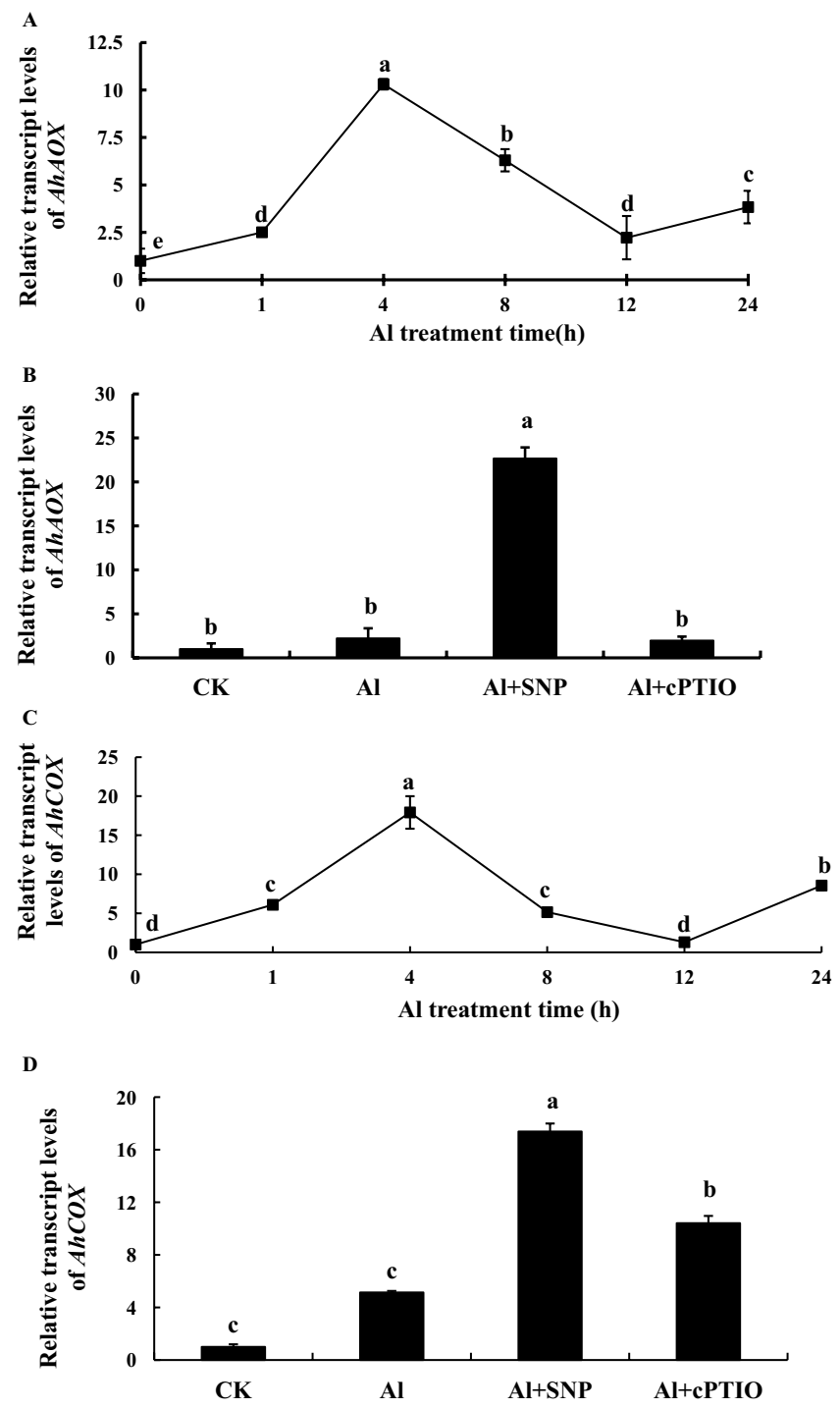

Figure 6. The expression of alternative oxidase $(A h A O X)$ and cytochrome oxidase $(A h C O X)$ at different times $(A, C)$ and different treatments for $12 \mathrm{~h}(\mathrm{~B}, \mathrm{D})$ under $\mathrm{Al}$ stress, respectively. Each data in figure represents the mean \pm SD of three experiments. Different lower case letters indicate significance at $P<0.05$ compared to the control.

the activities of mitochondrial antioxidant enzymes (SOD, APX) to scavenge excess ROS, reduces the level of mitochondrial membrane lipid peroxidation to maintain the normal physiological function of mitochondria, thus inhibiting the occurrence of PCD.

\section{Methods}

Plant material and treatments. $75 \%$ alcohol soaked in the seeds of Zhonghua 2 (Al-sensitive peanut variety) for $30 \mathrm{~s}$. Peanut seeds were germinated for 4 days in the moist sand at $26^{\circ} \mathrm{C}$ under dark condition. After the seed coat was removed, the germinated peanut seed was transplanted into a modified 1/5 Hoagland nutrient solution, which was changed every two days. The peanut seedlings of two leaf stage were pretreated for $24 \mathrm{~h}$ in a solution containing $0.1 \mathrm{mmol} \cdot \mathrm{L}^{-1} \mathrm{CaCl}_{2}(\mathrm{pH} 4.2)$. Some seedlings were respectively treated with $100 \mu \mathrm{mol} \cdot \mathrm{L}^{-1}$ $\mathrm{AlCl}_{3}$ containing $0.1 \mathrm{mmol} \cdot \mathrm{L}^{-1} \mathrm{CaCl}_{2}(\mathrm{pH} 4.2)$ at different times $(0 \mathrm{~h}, 1 \mathrm{~h}, 4 \mathrm{~h}, 8 \mathrm{~h}, 12 \mathrm{~h}$, and $24 \mathrm{~h})$. In addition, the following combination treatments were cultured for $12 \mathrm{~h}$ : (1) $0.1 \mathrm{mmol} \cdot \mathrm{L}^{-1} \mathrm{CaCl}_{2}(\mathrm{pH} 4.2)(\mathrm{CK})$; (2) $100 \mu \mathrm{mol} \cdot \mathrm{L}^{-1}$ $\mathrm{AlCl}_{3}$ (Al); (3) $100 \mu \mathrm{mol} \cdot \mathrm{L}^{-1} \mathrm{AlCl}_{3}+200 \mu \mathrm{mol} \cdot \mathrm{L}^{-1} \mathrm{SNP}(\mathrm{Al}+\mathrm{SNP})$; (4) $100 \mu \mathrm{mol} \cdot \mathrm{L}^{-1} \mathrm{AlCl}_{3}+50 \mu \mathrm{mol} \cdot \mathrm{L}^{-1} \mathrm{cPTIO}$ (Al+cPTIO), cPTIO (2-(Carboxyphenyl)-4,4,5,5-tetramethylimidazoline-4-oxyl-3-oxide). After each treatment, 15 peanut root tips were collected.

Determination of root cell death. Fresh roots were stained with $0.25 \%(\mathrm{w} / \mathrm{v})$ Evans blue solution for $15 \mathrm{~min}$. After washing with deionized water for $10 \mathrm{~min}$, ten root tips $(10 \mathrm{~mm})$ were excised and digested or $1 \mathrm{~h}$ in $4 \mathrm{mlN}, \mathrm{N}$-dimethylformamide at room temperature. The absorbance of Evans blue was measured at $600 \mathrm{~nm}^{40}$. 
a

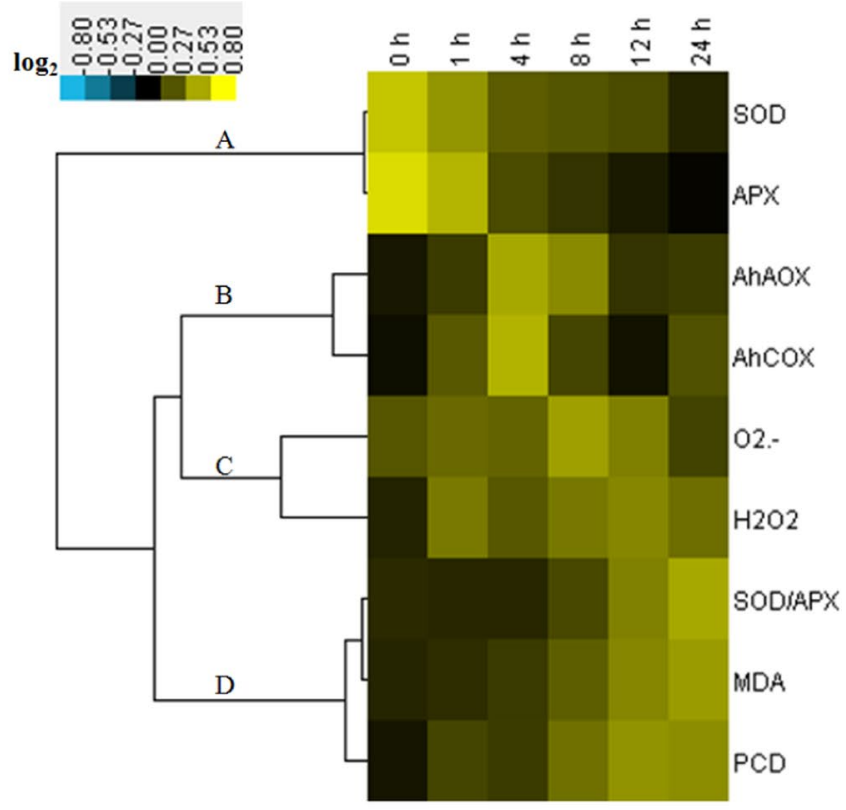

b

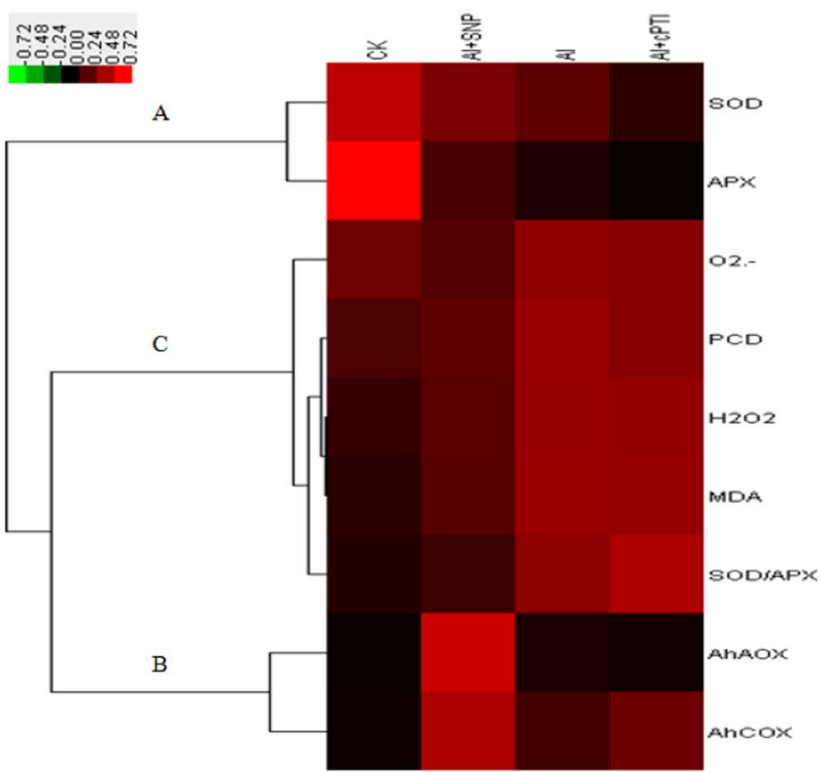

Figure 7. (a) Hierarchical cluster analysis of mitochondrial physiological parameters (SOD and APX (A), AhAOX and $A h C O X(B), \mathrm{O}_{2} \cdot{ }^{-}$and $\mathrm{H}_{2} \mathrm{O}_{2}$ (C), SOD/APX, MDA, and cell death (D)) in peanut root tips under different $\mathrm{Al}$ treatment time. (b) Hierarchical cluster analysis of mitochondrial physiological parameters (SOD and APX (A), AhAOX and AhCOX (B), $\mathrm{O}_{2}{ }^{-}, \mathrm{H}_{2} \mathrm{O}_{2}, \mathrm{SOD} / \mathrm{APX}, \mathrm{MDA}$, and cell death (C)) in the root tips of peanut under different treatments. Resulting tree diagram was obtained by using Cluster 3.0 software and Java Treeview. The cluster color bar was shown as $\log _{2}$ fold change.

Isolation of mitochondria from the root tips of peanut. According to Panda's method ${ }^{37}$, mitochondria were separated from peanut root tips. After rinsing with distilled water, $5 \mathrm{ml}$ mitochondrial extract buffer $(0.3$ $\mathrm{mol} \cdot \mathrm{L}^{-1}$ mannitol, $25 \mathrm{mmol} \cdot \mathrm{L}^{-1}$ MOPS-KOH $(\mathrm{pH} 7.8), 10 \mathrm{mmol} \cdot \mathrm{L}^{-1}$ tricine, $8 \mathrm{mmol} \cdot \mathrm{L}^{-1}$ cysteine, $1 \mathrm{mmol} \cdot \mathrm{L}^{-1}$ EGTA, $0.1 \%(\mathrm{w} / \mathrm{v}) \mathrm{BSA}$, and $1 \%(\mathrm{w} / \mathrm{v})$ PVP-40) were used to homogenized about $3 \mathrm{~g}$ fresh treated root tips on ice-bath. After $15 \mathrm{~min}$ centrifugation at $1500 \times \mathrm{g}$, the homogenate supernatant was centrifuged at $14000 \times \mathrm{g}$ for $15 \mathrm{~min}$. The precipitate was washed for 3 times by using mitochondrial suspension buffer $\left(0.4 \mathrm{mo} \cdot \mathrm{L}^{-1} \mathrm{manni}-\right.$ tol, $1 \mathrm{mmol} \cdot \mathrm{L}^{-1} \mathrm{EGTA}, 10 \mathrm{mmol} \cdot \mathrm{L}^{-1}$ tricine, $\mathrm{pH}$ 7.2). The final pellet was resuspended with mitochondrial suspension buffer of appropriate volume. To detect the viability of mitochondria, a suspension stained with $0.02 \%$ Janus Green B was observed under oil microscope. According to the methods of Braidot et al. ${ }^{41}$ and Zhang ${ }^{42}$, the 


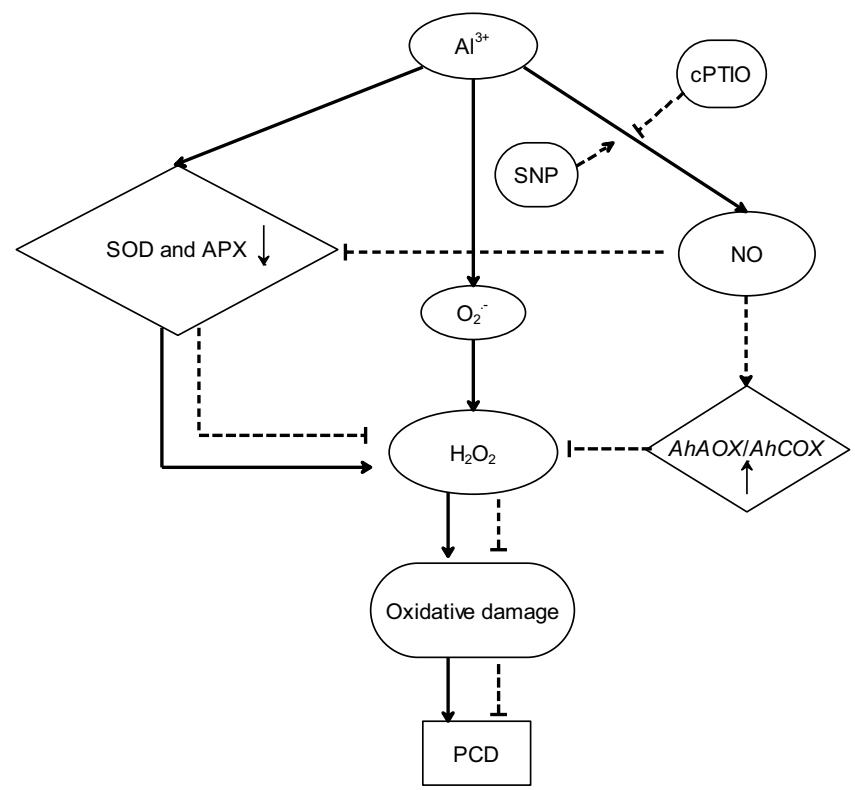

Figure 8. A proposed model for the role of $\mathrm{NO}$ in Al-induced $\mathrm{PCD}$ in the root tips of peanut. $\mathrm{Al}$ stress decreased the activities of SOD and APX, then led to the accumulation of ROS $\left(\mathrm{O}_{2} \cdot{ }^{-}\right.$and $\left.\mathrm{H}_{2} \mathrm{O}_{2}\right)$ contents and oxidative damage, which resulted in PCD occurrence. NO partially prevented Al-induced decay of activities of SOD and APX, enhanced the expression of $A h A O X$ and $A h C O X$, then reduced ROS production, which inhibited the production of PCD. The solid line represents $\mathrm{Al}^{3+}$ effect. The dashed line represents the inhibitory effect of NO on cell death. The sharp head represents promotion, whereas the flat head represents suppression.

membrane potential and Cyt c value were detected, respectively. The method of Bradford ${ }^{43}$ was used to determine protein concentration, which represented the mitochondrial concentration.

Assay of mitochondrial enzyme activities. The activity of mitochondrial SOD was determined by nitroblue tetrazolium (NBT) display method ${ }^{44}$. The total volume of $3 \mathrm{~mL}$ mixture included $1.5 \mathrm{~mL}$ of $0.05 \mathrm{~mol} \cdot \mathrm{L}^{-1}$ phosphate buffer ( $\mathrm{pH} 7.8$ ), $0.3 \mathrm{~mL}$ of $130 \mathrm{mmol} \cdot \mathrm{L}^{-1} \mathrm{Met}, 0.3 \mathrm{~mL}$ of $750 \mu \mathrm{mol} \cdot \mathrm{L}^{-1} \mathrm{NBT}, 0.3 \mathrm{~mL}$ of $100 \mu \mathrm{mol} \cdot \mathrm{L}^{-1}$ EDTA-Na $2,0.3 \mathrm{~mL}$ of $20 \mu \mathrm{mol} \cdot \mathrm{L}^{-1}$ riboflavin, $0.05 \mathrm{~mL}$ mitochondria extract, and $0.25 \mathrm{~mL}$ distilled water, respectively. 4 to 6 tubers were used as control, which the enzyme solution was replaced with buffer. After blending, two control tubes were placed in the dark, and other tubes under $4000 \mathrm{Lx}$ fluorescent lamp were reacted for $20 \mathrm{~min}$ (the consistent light situation was required, the reaction time shortened at high temperature but the reaction time extension at low temperature). After the reaction ended, taking the control tube treated with dark as blank, $\mathrm{OD}_{560}$ of other tube were determined respectively. $50 \%$ suppression of NBT photoredox reaction was one enzyme activity unit. SOD activity $=2 \times\left[\mathrm{OD}_{560}(\right.$ control $)-\mathrm{OD}_{560}($ sample tube $\left.)\right] \times$ volume of sample tube $(\mathrm{mL}) /$ $\mathrm{OD}_{560}$ (control) $\times$ Weight $\times$ volume of solution determined $(\mathrm{mL})$. The unit of enzyme activity was $\mathrm{U} \cdot \mu \mathrm{g}^{-1}$ Pro. The activity of mitochondrial APX was determined as follows ${ }^{45} .3 \mathrm{~mL}$ reaction mixture contained $50 \mathrm{mmol} \cdot \mathrm{L}^{-1}$ $\mathrm{K}_{2} \mathrm{HPO}_{4}-\mathrm{KH}_{2} \mathrm{PO}_{4}$ buffer ( $\mathrm{pH} 7.0$ ), $0.1 \mathrm{mmol} \cdot \mathrm{L}^{-1}$ EDTA-Na, $0.3 \mathrm{mmol} \cdot \mathrm{L}^{-1}$ AsA, and $0.1 \mathrm{~mL}$ mitochondrial extract. After adding $\mathrm{H}_{2} \mathrm{O}_{2}$, the absorbance changes within 10 to $30 \mathrm{~s}$ at $290 \mathrm{~nm}$ were immediately determined at $20^{\circ} \mathrm{C}$ and the reduction of AsA and enzyme activity in unit time were calculated. The unit of enzyme activity was $\mu \mathrm{mol} \mathrm{ASA} \cdot \mathrm{mg}^{-1}$ Pro $\cdot \mathrm{min}^{-1}$.

Detection of $\mathrm{O}_{2} \cdot{ }^{-}$production rate and $\mathrm{H}_{2} \mathrm{O}_{2}$ content. The production rate of superoxide anion free radical $\left(\mathrm{O}_{2} \cdot{ }^{-}\right)$was determined according to the method of $\mathrm{Zhan}$ et al. ${ }^{15} .0 .5 \mathrm{~mL}$ of mitochondrial extract was put into a test tube, respectively. Then $0.5 \mathrm{~mL}$ of $50 \mathrm{mmol} \cdot \mathrm{L}^{-1}$ phosphate buffer $(\mathrm{pH} 7.8)$ and $1 \mathrm{~mL}$ of $1 \mathrm{~mol} \cdot \mathrm{L}^{-1}$ hydroxylamine hydrochloride were added successively. After mixing, the mixture was kept for $1 \mathrm{~h}$ at room temperature. After $1 \mathrm{~mL} 17 \mathrm{mmol} \cdot \mathrm{L}^{-1}$ aminobenzene sulfonic acid and $1 \mathrm{~mL} 7 \mathrm{mmol} \cdot \mathrm{L}^{-1}$ alpha naphthylamine were added, mixing and displaying for $20 \mathrm{~min}$ at room temperature. With $0.5 \mathrm{~mL}$ phosphate buffer as a blank control, the absorbance at $530 \mathrm{~nm}$ was determined. According to the equation of hydroxylamine and $\mathrm{O}_{2}{ }^{-{ }^{-}}$, the formula $\left[\mathrm{O}_{2}{ }^{-}\right]=2\left[\mathrm{NO}_{2}{ }^{-}\right]$was used to express the production rate of $\mathrm{O}_{2}{ }^{--}$by stoichiometry. Nitrite content was calculated by the standard curve. According to the method of $\operatorname{Sergiev}^{46}, \mathrm{H}_{2} \mathrm{O}_{2}$ content was measured. $1 \mathrm{~mL}$ of mitochondrial extract, $2 \mathrm{~mL}$ of $1 \mathrm{~mol} \cdot \mathrm{L}^{-1} \mathrm{KI}$, and $1 \mathrm{~mL}$ of $0.1 \mathrm{~mol} \cdot \mathrm{L}^{-1}$ phosphate buffer (pH 7.0) were added to the test tube. According to a $\mathrm{H}_{2} \mathrm{O}_{2}$ standard curve, the absorbance at $390 \mathrm{~nm}$ measured after $20 \mathrm{~min}$ shake was converted into $\mathrm{H}_{2} \mathrm{O}_{2}$ concentrations.

Determination of mitochondrial MDA content. $\quad 0.2 \mathrm{~mL}$ mitochondrial extract (distilled water as a control) was put into a test tube and was added by $1 \mathrm{~mL} 0.6 \%$ thiobarbituric acid (TBA). Then it was bathed in boiling water for $15 \mathrm{~min}$. After cooling, the homogenate was centrifuged at $1500 \times \mathrm{g}$ for $10 \mathrm{~min}$ to measure the absorbance at $532 \mathrm{~nm}, 600 \mathrm{~nm}$, and $450 \mathrm{~nm}$, respectively. Malondialdehyde (MDA) content was calculated according to the method of Zhan et al. ${ }^{15}$. 
Transcript analysis of $A h A O X$ and $A h C O X$ by quantitative RT-PCR. Peanut root tips were used to extract total RNA. Primer sequences of AhAOX (accession No. AES98635.1) were 5'-AGGTCACTCCGCAGGTTTCAG-3' (forward) and $5^{\prime}$-AACTCCCTGGACAACAAGAACAAG- $3^{\prime}$ (reverse). The primer sequences of AhCOX (accession No. AES58587.1) were 5'- TAGAGATCGGAGGTATTTGGCCC -3' (forward) and 5'CGCGAGTATAGCATGATGAGCC $-3^{\prime}$ (reverse). After the reverse transcription of total RNA, the reaction system was as follows: $10 \mu \mathrm{L}$ of $2 \times$ SybrGreen qPCR Master Mix, $2 \mu \mathrm{L}$ of cDNA, $1 \mu \mathrm{L}$ of primer $\mathrm{F}\left(10 \mu \mathrm{mol}^{-1} \mathrm{~L}^{-1}\right), 1 \mu \mathrm{L}$ of primer $\mathrm{R}(10$ $\mu \mathrm{mol} \cdot \mathrm{L}^{-1}$ ), and $6 \mu \mathrm{L}$ of $\mathrm{ddH}_{2} \mathrm{O}$. The amplification procedure was conducted using at $95^{\circ} \mathrm{C}$ for $10 \mathrm{~min}$ (initial), $95^{\circ} \mathrm{C}$ for $10 \mathrm{~s}$ (melting), $55^{\circ} \mathrm{C}$ for $10 \mathrm{~s}$ (annealing), and $72^{\circ} \mathrm{C}$ for $20 \mathrm{~s}$ (extend) for 40 cycles. All quantifications were normalized to amplification of Ahactin (EU982407). The amount of gene expression was calculated by $2^{-} \Delta \Delta \mathrm{Ct}$ relative quantitative analysis. The forward and reverse primer sequences of Ahactin were $5^{\prime}$-ATGGAGAAGATCTGGCATCATACC-3' and 5'- TGGCAACATACATAGCAGGGG-3', respectively.

Hierarchical cluster analysis. Hierarchical cluster analysis was performed by Cluster 3.0 software ${ }^{47}$. Java Treeview was used to display the resulting tree figures ${ }^{48}$.

Statistical analysis. All experiments were repeated for three times. The results were processed using one-way analysis of variance (ANOVA). The data represent the mean \pm SD. The significant differences among the treatments were statistically evaluated by Student's paired $t$ test.

\section{References}

1. Yamamoto, Y., Kobayashi, Y., Rama, D. S., Rikiishi, S. \& Matsumoto, H. Aluminum toxicity is associated with mitochondrial dysfunction and the production of reactive oxygen species in plant cells. Plant Physiol. 128, 63-72 (2002).

2. Nunes-Nesi, A., Santos, B. D., Inostroza-Blancheteau, C., Fernie, A. R. \& Araujo, W. L. The complex role of mitochondrial metabolism in plant aluminum resistance. Trends Plant Sci. 19, 399-407 (2014).

3. Pan, J., Zhu, M. \& Chen, H. Aluminum-induced cell death in root-tip cells of barley. Environ. Exp. Bot. 46, 71-79 (2001).

4. Zheng, K. et al. Programmed cell death-involved aluminum toxicity in yeast alleviated by antiapoptotic members with decreased calcium signals. Plant Physiol. 143, 38-49 (2007).

5. Huang, W. et al. Aluminum induces rapidly mitochondria dependent programmed cell death in Al-sensitive peanut root tips. Bot. Stud. 55, e67 (2014)

6. He, H., Zhan, J., He, L. \& Gu, M. Nitric oxide signaling in aluminum stress in plants. Protoplasma 249, 483-492 (2012).

7. He, H. Y., He, L. F., Li, X. F. \& Gu, M. H. Effects of sodium nitroprusside on mitochondrial function of rye and wheat root tip under aluminum stress. J. Plant. Physiol. Mol. Biol. 32, 239-244 (2006).

8. He, H., Huang, W., Oo, T. L., Gu, M. \& He, L. F. Nitric oxide inhibits aluminum-induced programmed cell death in peanut (Arachis hypoganea L.) root tips. J. Hazard. Mater. 333, 285-292 (2017).

9. Belgni, M. V., Fath, A., Bethke, P. C., Lamattina, L. \& Jones, R. L. Nitric oxide acts as an antioxidant and delays programmed cell death in barley aleurone layers. Plant Physiol. 129, 1642-1650 (2002).

10. Zhan, J., Kou, R. J., Li, C. Z., He, H. Y. \& He, L. F. Effects of aluminum on physiological characteristics of mitochondrial membrane in peanut root tips. Acta Agronomica Sinica 35, 1059-1067 (2009).

11. Li, Z. \& Xing, D. Mechanistic study of mitochondria-dependent programmed cell death induced by aluminum phytotoxicity using fluorescence techniques. J. Exp. Bot. 62, 331-343 (2011).

12. Tiwari, B. S., Belenghi, B. \& Levine, A. Oxidative stress increased respiration and generation of reactive oxygen species, resulting in ATP depletion, opening of mitochondrial permeability transition, and programmed cell death. Plant Physiol. 128, 1271-1281 (2002).

13. Vacca, R. A. et al. Production of reactive oxygen species, alteration of cytosolic ascorbate peroxidase, and impairment of mitochondrial metabolism are early events in heat shock-induced programmed cell death in tobacco Bright-Yellow 2 cells. Plant Physiol. 134, 1100-1112 (2004).

14. Vacca, R. A. et al. Cytochrome $\mathrm{c}$ is released in a reactive oxygen spcies-dependent manner and is degraded via capase-like protease in tobacco Bright-Yellow 2 cells en route to heat shock-induced cell death. Plant Physiol. 141, 208-219 (2006).

15. Zhan, J., Li, W., He, H., Li, C. \& He, L. F. Mitochondrial alterations during Al-induced PCD in peanut root tips. Plant Physiol. Biochem. 75, 105-113 (2014).

16. Huang, W. et al. Reactive oxygen species burst induced by aluminum stress triggers mitochondria-dependent programmed cell death in peanut root tip cells. Plant Physiol. Biochem. 82, 76-84 (2014).

17. Liu, S. G., Zhu, D. Z., Chen, G. H., Gao, X. Q. \& Zhang, X. S. Disrupted actin dynamics trigger an increment in the reactive oxygen species levels in the Arabidopsis root under salt stress. Plant Cell Rep. 31, 1219-1226 (2012).

18. He, H. et al. Nitric oxide suppresses aluminum-induced programmed cell death in peanut (Arachis hypoganea L.) root tips by improving mitochondrial physiological properties. Nitric Oxide 74, 47-55 (2018).

19. Schutzendubel, A. et al. Cadmium-induced changes in antioxidative systems, hydrogen peroxide content, and differentiation in Scots pine roots. Plant Physiol. 127, 887-898 (2001).

20. Yakimova, E. T., Kapchina-Toteva, V. M. \& Woltering, E. J. Signal transduction events in aluminum-induced cell death in tomato suspension cells. J. Plant Physiol. 164, 702-708 (2007).

21. Zhang, H. et al. Effects of exogenous nitric oxide donor on antioxidant metabolism in wheat leaves under aluminum stress. Russ. J. Plant Physiol. 55, 469-474 (2008).

22. Wang, H. H., Huang, J. J. \& Bi, Y. R. Nitrate reductase-dependent nitric oxide production is involved in aluminum tolerance in red kidney bean roots. Plant Sci. 179, 281-288 (2010).

23. Xue, Y. J., Tao, L. \& Yang, Z. M. Aluminum-induced cell wall peroxidase activity and lignin synthesis are differentially regulated by jasmonate and nitric oxide. J. Agri. Food. Chem. 56, 9676-9684 (2008).

24. Zago, E. et al. Nitric oxide- and hydrogen peroxide-responsive gene regulation during cell death induction in tobacco. Plant Physiol. 141, 404-411 (2006).

25. Yang, L., Tian, D., Todd, C. D., Luo, Y. \& Hu, X. Comparative proteome analyses reveal that nitric oxide is an important signal molecule in the response of rice to aluminum toxicity. J. Proteom. Res. 12, 1316-1330 (2013).

26. Rodriguez-Serrano, M. et al. Cellular response of pea plants to cadmium toxicity: talk between reactive oxygen species, nitric oxide, and calcium. Plant Physiol. 150, 229-243 (2009).

27. Wang, J. \& Vanlerberghe, G. C. A lack of mitochondrial alternative oxidase compromises capacity to recover from severe drought stress. Physiol. Plant. 149, 461-473 (2013).

28. Wang, Y. S. \& Yang, Z. M. Nitric oxide reduces aluminum toxicity by preventing oxidative stress in the roots of Cassia tora L. Plant Cell Physiol. 46, 1915-1923 (2005). 
29. Correa-Aragunde, N., Foresi, N. \& Lamattina, L. Nitric oxide is a ubiquitous signal for maintaining redox balance in plant cells: regulation of ascorbate peroxidase as a case study. J. Exp. Bot. 66, 2913-2921 (2015).

30. Wang, Y. et al. Salt-induced hydrogen peroxide is involved in modulation of antioxidant enzymes in cotton. Crop J. 4, 490-498 (2016).

31. Fan, J. et al. Physiological and molecular mechanism of nitric oxide (NO) involved in Bermudagrass response to cold stress. PLoS ONE 10, e0132991 (2015).

32. Purvis, A. C. Role of the alternative oxidase in limiting superoxide production by plant mitochondria. Physiol. Plant. 100, 165-170 (1997).

33. Maxwell, D. P., Wang, Y. \& McIntosh, L. The alternative oxidase lowers mitochondrial reactive oxygen production in plant cells. Proc. Natl. Acad. Sci. USA 96, 8271-8276 (1999).

34. Robson, C. A. \& Vanlerberghe, G. C. Transgenic plant cells lacking mitochondrial alternative oxidase have increased susceptibility to mitochondria-dependent and -independent pathways of programmed cell death. Plant Physiol. 129, 1908-1920 (2002).

35. Vanlergerghe, G. C., Robson, C. A. \& Yip, J. Y. H. Induction of mitochondrial alternative oxidase in response to a cell signal pathway down-regulation the cytochrome pathway prevent programmed cell death. Plant Physiol. 129, 1829-1842 (2002).

36. Gray, G. R., Maxwell, D. P., Villarimo, A. R. \& McIntosh, L. Mitochondria/nuclear signaling of alternative oxidase gene expression occurs through distinct pathways involving organic acids and reactive oxygen species. Plant Cell Rep. 23, 497-503 (2004).

37. Panda, S. K., Yamamoto, Y., Kondo, H. \& Matsumoto, H. Mitochondrial alterations related to programmed cell death in tobacco cells under aluminum stress. C. R. Biol. 331, 597-610 (2008).

38. Van Aken, O., Giraud, E., Clifton, R. \& Whelan, J. Altenative oxidase: a target and regulator of stress responses. Physiol. Plant. 137, 354-361 (2009).

39. Minibayeva, F., Dmitrieva, S., Ponomareva, A. \& Ryabovol, V. Oxiative stress-induced autophagy in plants: The role of mitochondria. Plant Physiol. Biochem. 59, 11-19 (2012).

40. Achary, V. M. M., Jena, S., Panda, K. K. \& Panda, B. B. Aluminum induced oxidative stress and DNA damage in root cells of Allium cepa L. Ecotox Environ Saf 70, 300-310 (2008).

41. Braidot, E., Petrussa, F., Macri, F. \& Vianello, A. Plant mitochondrial electrical potential monitored by fluorescence quenching of rhodamine 123. Biol Plant (Prague) 41, 193-201 (1998).

42. Zhang, J. (Editor-in-chief). Modern Pharmacological Experimental Methods (M). Beijing: Beijing Medical University and China Union Medical University Associated Press, p1228-1229 (1998).

43. Bradford, M. M. A rapid and sensitive method for the quantitation of microgram quantities of protein utilizing the principle of protein-dye binding. Anal. Biochem. 72, 248-254 (1976).

44. Beauchamp, C. \& Fridovich, I. Superoxide dismutase: improved assays and an assay applicable to acrylamide gels. Anal. Biochem. 44, 276-287 (1971)

45. Nakano, Y. \& Asada, K. Hydrogen peroxide is scavenged by ascorbate-specific peroxidase in spinach chloroplasts. Plant Cell Physiol. 22, 867-880 (1981)

46. Sergiev, I. A., Alexieva, V. \& Karanov, E. Effect on spennine, atrazine and combination between them on some endogenous protective systems and stress markers in plants. Compt. Rend. Acad. Bulg. Sci. 51, 121-128 (1997).

47. de Hoon, M. J. L., Imoto, S., Nolan, J. \& Miyano, S. Open source clustering software. Bioinformatics 20, 1453-1454 (2004).

48. Chan, Z., Bigelow, P. J., Grumet, R. \& Loescher, W. Comparison of salt stress resistance genes in transgenic Arabidopsis thaliana indicates that extent of transcriptomic change may not predict secondary phenotypic or fitness effects. Plant Biotechnol. J. 10, 284-300 (2012).

\section{Acknowledgements}

This work was supported by the National Natural Science Foundation of China (No. 31660350, 31660352, 31560346, 31260296, and 31301249), Guangxi Natural Science Foundation (Grant No. 2014GXNSFAA118074 and 2015GXNSFAA139079), and the Science \& Technology Development Fund of Guangxi Academy of Agricultural Sciences (Guinongke2017JZ11 and Guinongke2017JZ21). Thank Liao Boshou, a researcher from Oil Crops Research Institute of Chinese Academy of Agricultural Sciences, for his peanut variety.

\section{Author Contributions}

H.H. performed experiments and wrote the MS. T.L.O. and W.H. was responsible for data analysis. L.F.H. and M.G. planned and supervised the study. All authors read and approved the final MS.

\section{Additional Information}

Competing Interests: The authors declare no competing interests.

Publisher's note: Springer Nature remains neutral with regard to jurisdictional claims in published maps and institutional affiliations.

Open Access This article is licensed under a Creative Commons Attribution 4.0 International License, which permits use, sharing, adaptation, distribution and reproduction in any medium or format, as long as you give appropriate credit to the original author(s) and the source, provide a link to the Creative Commons license, and indicate if changes were made. The images or other third party material in this article are included in the article's Creative Commons license, unless indicated otherwise in a credit line to the material. If material is not included in the article's Creative Commons license and your intended use is not permitted by statutory regulation or exceeds the permitted use, you will need to obtain permission directly from the copyright holder. To view a copy of this license, visit http://creativecommons.org/licenses/by/4.0/.

(C) The Author(s) 2019 